\title{
SCIENTIFIC VIEWS OF MILORAD EKMEČIĆ ACCORDING TO THE ORIGINS OF NAČERTANIJE: HIS GOALS AND INTERPRETATIONS
}

\begin{abstract}
Researching for the needs of the doctoral dissertation on the topic "Life and Work of Milorad Ekmečić (1928-2015)”, we noticed that this distinguished Yugoslavian and Serbian historian, in one period of his career, had shown special interest in search for the true creator of "Načertanije" - unofficial foreign policy program of the Principality of Serbia. Starting from the principle that in historical science nothing is explored to the end, he tackled the issue with almost axiomatic claim that Ilija Garašanin is the author of this writing. Thanks to decades of research experience, extraordinary erudition and a good command of archive material and relevant literature he managed to perform critical scrutiny. He discovered data that shed a whole new light on the background of this document. He wrote about its historical meaning and goals, but also about different interpretations of the essence of "Načertanije", which once had a non-scientific character. He thus gave another original contribution to our historiography.
\end{abstract}

KEYWORDS: Milorad Ekmečić; Načertanije; Illyrian movement; David Urquart; Adam Czartoryski; František Zach; Ilija Garašanin.

1 jovan.aleksic@pr.ac.rs

This paper was submitted on June $16^{\text {th }}, 2021$ and accepted for publication at the meeting of the Editorial Board held on November $16^{\text {th }}, 2011$. 
Milorad Ekmečić is one of the biggest names in Balkan historiography of the second half of the 20th and the beginning of the 21st century. Creating for more than six decades he left behind an indelible scientific mark, as evidenced by more than 300 bibliographic items and several dozen generations of educated historians. Owing to a rarely seen enthusiasm he removed the decades of accumulated dust from extremely important sources of southeastern and central Europe, and he gave them the appropriate form and interpretation. His main area of scientific interest was the development of the national revival of the South Slavs, their interrelationships, their similarities and differences, as well as the influence of great forces on their shaping. A real example of this is his study of the conditions in which the foreign policy program known as "Načertanije" was created. Driven by a strong research curiosity he invested great efforts to find who the real inspirers, contributors and creators of this writing were, which had provoked numerous controversies from the day of its inception. The results of his study were extremely interesting. For example, he showed that the roots of the "Načertanije", were intertwined with the Illyrian movement. In his work "Church and the nation at the Croats" (original: Црква и наиија код Хрвата) claims that "the highest historical achievement of Croatian liberal Catholicism", was manifested in the creation of the first Serbian national doctrine known as "Načertanije" (Екмечић, 2002, p. 122). On the pages of the same article, he underlined that many roman catholic priests from Dalmatia, Slavonia and Bosnia and Herzegovina participated in the making of manuscript, and later were Garšanin's trustees in the implementation of the idea of the unification of Bosnia and Herzegovina with Serbia. He mentioned Matija Ban and Tomo Kovačević as the most prominent among them. "In general, the main historical contribution of liberal Catholicism was in inspiring political programs for the creation of a common Yugoslavian state with the Serbs and Belgrade as its capital." (Екмечић, 2002, p. 122).

Ekmečić believed that any research endeavor should be aimed at reconstructing the history of the origin of the Serbian national doctrine in 1844. "We should start from the basic point that it was created within the goals of the Serbian revolution of 1804-1815, but that the Serbs did not formulate it in that period, rather than accepted and refined when it was developed by British and French diplomats in 1832." (Екмечић, 2002, p. 99). He assigns the greatest role in creating this document to David Urquart, a controversial British diplomat. In his monumental work Creation of Yugoslavia 
(original: Стварање Југославије), he writes that Urquhart, acting as the secretary of the British embassy in Constantinople, met with prince Miloš and then wrote reports, whose transcribed version was found among the papers of the Polish nobleman Adam Czartoryski; the folder also contained the documents on the basis of which "Načertanije" was later created (Екмечић, 1989, p. 225). According to Ekmečić research, the Serbian foreign policy program was formed by a Scot (David Urquart), a Czech (Frantiseh Zach) and a Pole (Adam Czartoryski), while Ilija Garašanin only shaped and formulated it (Екмечић, 1989, p. 224-228). In his mentioned work "Church and the nation at the Croats", Ekmečić says that Urquart published all the essential ideas of "Načertanije" was even earlier in journals "Portfolio" and "British and Foreign Quarterly Review", advising the Serbs that it was better not to cross the borders of the Ottoman Empire in their struggle for independence (Екмечић, 2002, p. 122).

Through his article "Marginalities about Serbian-Bulgarian relations 1844-1851." (original: Маргиналије о српско-бугарским везама 18441851.) we learn that Urquart advocated for the creation of the Danube Confederation in his work from 1837. - La Turquie ses ressources, son organisation municipale, son commerce, "under the protection of Austria" which would consist of Serbia (potentially united with Bosnia), Bulgaria, Moldova and Wallachia (Екмечић, 2000, pp. 232279).

What is the historical meaning of these actions of Urquart, in which both Zach and Czartoryski took part? According to Ekmečić, their goal was to repel Serbia from Russia and the pan-Slavic movement through its westernization, which was equated with gaining independence. Creating a plan for the Serbian national movement for the coming decades, these famous foreigners of Serbian history believed that Serbia should be incorporated into the bloc of "Western Slavs" as opposed to Russian imperial pan-Slavism, which they identified with imperialism (Екмечић, 2002, pp. 112-116). Judging by the prints of material for the history of the creation of "Načertanije" from the Polish, British, French, Austrian, Russian and Yugoslavian archives, Urquart worked on it devotedly even before the end of the Greek National Revolution (1821-1830). ${ }^{2}$ Ekmečić formulated a thesis about the fear of the great western powers saying that the Serbs could become "Russian horsemen" on the warm seas,

2 According to Ekmečić testimony, the mentioned documents "are destroyed at the beginning of the civil war in Sarajevo at 1992." Translated by the author. 
which had obviously come to the fore again. In his last synthesis Long Movement between Slaughter and Plowing (original: Дyго кретање између клања и орања), he enigmatically drew the thought that in the year of the official creation of "Načertanije" (1844.) the same

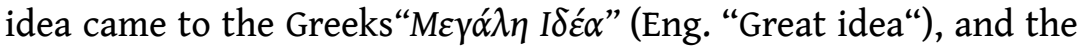
Italians "Speranze d'Italia" (Cesare Balbo) making them the two fateful drafts of national doctrines. He did not clarify whether there was any connection between these plans or whether it was a mere coincidence (Екмечић, 2007, pp. 218-220). Through the text of the article "European Background Načertanije by Ilija Garašanin from 1844" (original: Европска позадина Начертанија Илије Гарашанина из 1844.) he stated that of these three great national doctrines, two "historically failed" and the third, the Italian, won through the rise of the ideas of the catholic forces in European development (Екмечић, 2002, р. 117).

It should be pointed out that Ekmečić was especially concerned with the ideological draft of Cesar Balbo from 1844. and its long-term influences on European, Yugoslav and Serbian history. In his work "Balkan policy of Austro-Hungary after the Berlin Congress" (original: Балканска политика Аустро-Угарске после Берлинског конгреса) he pointed out that Balbo's plan was in fact a strategic minimum to which all Catholic and non-Catholic western states should adhere. What did such a foreign policy program mean? Ekmečić showed that, as Cesare Balbo predicted, the Italian national unification would take place and had to be fulfilled as a vow of all civilized countries - which did not include Russia - to find a place under the sun for the maintenance of the Habsburg monarchy and when its "posthumous bell starts ringing, with the fall of the Italian and German provinces" (Екмечић, 2007, p. 145). Publishing a translation of this writing as a special attachment to the collection of works "Dialogue of Past and Present" (original: Дијалог прошлости u садашњости) ${ }^{3}$ Ekmečić presented the essence of Balbo's idea, which implied the necessity that "Austria replaces Italian and German provinces with Turkish ones" (Екмечић, 2002, p. 229). Following one of Ekmečić theses, these desertions of Habsburg penetration on the European southeast dated back to the time of Eugene of Savoy, and only continued during the 19th century. Based on his translation, we can conclude that Balbo's writing had its own, cultural-racist dimension saying, that Slavic peoples cannot be "civilized"

3 Екмечић, 2002, pp. 229-234. 
without the Germanization of their areas. His thoughts regarding the colonization of German settlers on the fertile Slavic fields: "It's not a utopia that Germany should leave Eastern Europe. The opposite of that is to think that utopia can be created on east without Germany" (Екмечић, 2002, p. 234). He obviously held the position that civilization among the Slavic peoples should be carried out by the Germans - Prussian Germans to Poland, and Austrians to the Balkans.

Ekmečić proved that the Habsburg court co-opted the manuscript as their historical program from 1866, when they finally lost the provinces during the war with Prussia and Italy. Then, to his knowledge, a definite decision was made not to allow Serbian national unification at any cost. He claimed that the decision was made on to the possibility of the Serbian liberation of Bosnia and Herzegovina, which would fundamentally threaten the existence of the Habsburg state existence (Екмечић, 2007, p. 145). Therefore, Serbian "Načertanije" came into conflict with the Habsburg version by Cesare Balbo, and the Serbian national movement became the mortal enemy of "Black and Yellow Monarchy".

In general, it seems to be the most expedient judgment about the most important Serbian foreign policy plan of the 19th century that Ekmečić presented in Creation of Yugoslavia through the words that the "Načertanije" was not the fruit of Ilija Garašanin's ingenuity, nor his advisor Frantisek Zach, nor the activities of prince Adam Czartoryski, but that it was "squeezed juice of the Serbian historical experience of the struggle for an independent and democratic state from the time of Prince Miloš and the conflict with Russian diplomacy in 1833. (...) this was the result of verified connections with representatives of the surrounding national movements" (Екмечић, 1989, p. 479). He believed that only ignorance of the true nature of the origin of that document determined a part of historians "to assess it as a source of Greater Serbian hegemony" (Екмечић, 2002, р. 122).

It should be noted that Ekmečić found that the "Načertanije" the so-called "greater Serbian goals" were not of recent date, but had a deep root that stretched back to the 1860s when French diplomacy aided the creation of Party of Rights in Croatia with the aim of catholic expansion. According to his research, the evaluation of "Načertanije" as a "project of Greater Serbian hegemony", had starting then, with the denial of its declared goal - the creation of a free Yugoslav state with Serbia as its Piedmont (Екмечић, 2002, p. 98). 
Yet, the real misunderstandings in scientific circles about the nature of "Načertanije" emerged only when the German political ideology after 1930 began to accuse Serbia of being responsible for the 1914 war, which was tied to its entire national policy. Ekmečić believed that the German attacks on Serbia and its national doctrine were assisted by the last Austro-Hungarian governor of Bosnia and Herzegovina, Stjepan Sarkotić, through writing of the preface to the German protocol of the process of Banja Luka from the First World War (Екмечић, 2002, p. 98). "Under such circumstances scientists have made a mistaken assumption that it was Czartoryski in 1843 offered to the Serbian government one Polish project of Yugoslavian unification, and Garašanin made of that a Serbian project in 1844. What Czartoryski offered was not a Polish draft, but a broad program of Serbian gathering, that was leading to a broader Yugoslavian, which was created by Miloš Obrenović in 1833. From the Serbian program of Yugoslavian unity, Garašanin kept his meaning, but rejected Polish trust in the historical power of Croatian liberal Catholicism, as the basis of the real policy of a one state." (Екмечић, 1989, p. 484).

"Načertanije" was also marked as 'apple of discord' between Croatian and Yugoslavian oriented "representatives of the muse Clio" during the Second World War. ${ }^{4}$ In the period of socialist Yugoslavia, there was real flood of new-old assessments of "Načertanije" as "one of the sources for the greater Serbian aggression", it was a part of the wars on the territory of the former Yugoslavia. Ekmečić said that the assessments of Croatian historians Mirko Grmek, Marko Djidara and Neven Simac about "Načertanije" as an ideological draft of ethnic cleansing with the aim of creating a Greater Serbia (Grmek et al., 1993), "represented the cracking of the dam where irrational flood of similar writings around the world had led to the evaluation every word of the scientific research part of a conspiracy born in 1844." (Екмечић, 2002, p. 98).

Speaking of the famous term 'Greater Serbia', it is worth noting that Ekmečić dealt with it especially in his work "The Notion of a Greater Serbia according to World Models" (original: Појам Велике Србије према светским узорима), that was presented at an international scientific conference of the Serbian Academy of Sciences and Arts in Belgrade at the end of October 2002. In his view, 'Greater

4 Here, Ekmečić cites the example of Petar Šimunić's book "Načertanije: Secret document of Serbian national and foreign policy" (original: "Načertanije. Tajni spis srbske nacionalne i vanjske politike") (Šimunić, 1944). 
Serbia' presented a legitimate idea of the rights of the Serbian people to gather within its political borders all the provinces in which the Serbian people live. As in all other European models, this did not mean that only countries where the Serbian people live in the ethnic majority, so they would be already statistically entitled to it, this considered also those border zones where they lived as a significant ethnic group, although not the majority by a number. That indicates the aspiration to unite all ethnic areas of one nation, with the strategic encirclement of its borders, that, this is the basis of every sovereign state. He points out that a true understanding of the term "Greater Serbia" should always be observed in relation to historical standards of German and other European nations, He pointed out that the true understanding of the term 'Greater Serbia' should always be viewed in relation to the historical standards of German and other European nations, because it is one of the motives for the development of the Serbian past, which was European - conditioned from the beginning, experiencing ups and downs, as well as the final decline.

Studying the problems of the historical meaning of the first Serbian foreign policy doctrine, Ekmečić proved the correctness of his statement made in his work Creation of Yugoslavia - that nothing important happened in the Balkans without the direct or indirect participation of the great powers. In the mentioned book, in addition to the unpublished documents from the Yugoslav and European archives, he used the writings of one of the authors to build his views of "Načertanije", David Urquhart, ${ }^{5}$ to build his views, but also classics of Serbian historiography such as the works of Čedomilj Mijatović6, Milan Milićević, ${ }^{7}$ Dragoslav Stranjković, ${ }^{8}$ Ljubomir Durković-Jakšić, ${ }^{9}$ Vojislav Vučković. ${ }^{10}$ He also consulted foreign literature, mostly of Polish provenance. ${ }^{11}$ In his later works he dealt with this question including several more of his works which have been in the meantime created, ${ }^{12}$ but also arguably the most complete study of it - Book of Načertanije (original: Књига о Начертанију)

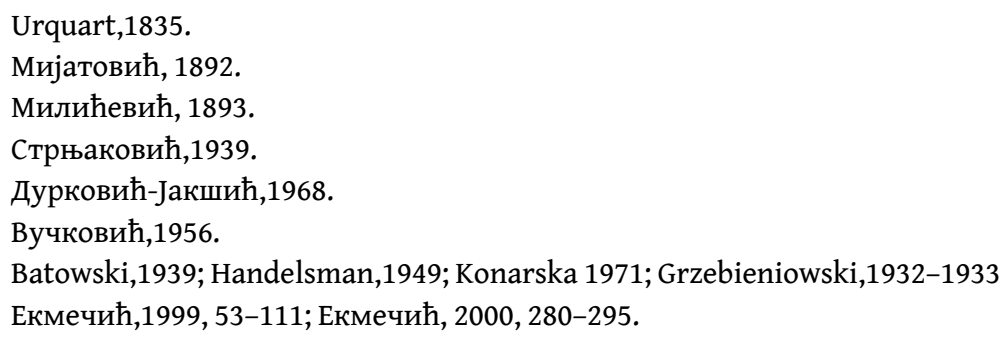


by Radoš Ljušić. ${ }^{13}$ As a new contribution to the study of this topic, at the end of his work European Background Načertanije by Ilija Garašanin from 1844 he added two attachments in English. The first is entitled Projet de Memoir of the Serbian Government, and the second (David Urquart): The Affairs of Serbia.

Based on thing said, we can conclude that Ekmečić, based on the original material and relevant historiographical literature, proved that "Načertanije" in fact, was not the fruit of Serbian political thought, but the work of three European diplomats and statesmen, who, out of their own interests, drew up a plan for Serbian national unification within the Yugoslav community. The entire history of this document was accompanied by numerous controversies, which Ekmečić, thanks to exhaustive archival research and reading volumes and volumes of books, successfully developed. The same is the case with malicious assessments and accusations against "Načertanije" which, according to Ekmečić were unscientific and served as an ideological justification for the expansion of other forces at the expense of Serbian interests. In his opinion, "the real opponents of the sober study of Načertanije are western generals, and not huge books that are written for their needs." (Екмечић, 2002, 129). Despite the fact that, this document, "entered into all the preambles of the indictment against the Federal Republic of Yugoslavia, of all individuals charged with war crimes in the civil war in Croatia and Bosnia and Herzegovina of the International Court of Justice in the Hague, as well as the International Criminal Tribunal for war crimes in Hague", his scientific view of "Načertanije" is clear: it was a doctrine whose ultimate goal was the creation of a Yugoslav state on the natural foundations of Serbian ethnic unification.

REFERENCES
Batowski, H. (1939). Podstawy Sojuszu Balkanskiego 1912. Studium z historii dyplomatycznej 1806-1912. Krakow: Polskie Towarzystwo dla Badań Europy Wschodniej i Bliskiego Wschodu.

Grmek, M. Đidara, M. Šimac, N. (1993). Le nettoyage ethnique. Documents historique sur une ideologie serbe. Paris: Fayard.

Grzebieniowski, dr. T. (1932). The Polish cause in England a century ago. The Slavonic (and East European) Rewiev, XI, London: Modern Humanities Research Association, 81-87.

Handelsman, M. (1949). Adam Czartoryski, II. Warzawa: Nakładem Towarzystwa Naukowego Warszawskiego.

13

Љушић,1993. 
Konarska, B. (1971). W krengu Hotelu Lambert. Wldyslaw Zamoyski w latach 1832-1847. Wroclow: Zakład Narodowy im. Ossolińskich.

Šimunić, P. (1944). Načertanije. Tajni spis srbske nacionalne i vanjske politike. Zagreb: Tipografija.

Urquart, D. (1835). England and Russia: being a fifth Edition of England, France, Russia and Turkey. London: James Ridgway \& Sons.

Вучковић, В. Ј. (1956). Политичка акција Србије у јужнословенским покрајинама Хабсбуршке монархије 1859-1874. Београд: Научно дело.

Дурковић-Јакшић, Љ. (1968). Бранислав. Први југословенски илегални лист 1844-1845. Београд: Научна књига.

Екмечић, М. (2002). Црква и нација код Хрвата. Oїлеgu из исӣорије. Београд: Службени лист СРЈ, 111-149.

Екмечић, М. (1989). Стварање Југославије, књ. 1-2. Београд: Просвета.

Екмечић, М. (1999). Географски непријатељ Србије (Улога католичке политичке идеологије у Источном питању 1844-1878). Oілеgи из исйорије, Београд: Службени лист СРЈ, 53-111.

Екмечић, М. (2000). Маргиналије о српско-бугарским везама 1844-1851. Револущ̧ија 1848. и Балкан. Нови Сад: Матица српска, 232-279.

Екмечић, М. (2000). Српско-бугарски односи половицом ХІХ века (18441853). Револуција 1848. и Балкан. Нови Сад: Матица српска, 280-296.

Екмечић, М. (2002). Европска позадина „Начертанија“ Илије Гарашанина из 1844. Дијалої йрошлосӣu и саgашњосӣи. Београд: Службени лист СРЈ, 95-137.

Екмечић, М. (2002). Улога католичке политичке идеологије у Источном питању 1844-1878. Дијалої ӣрошлосӣи и саgашњосӣu, Београд 2002: Служठени лист СРЈ, 213-139.

Екмечић, М. (2003). Појам Велике Србије према светским узорима. Вели-

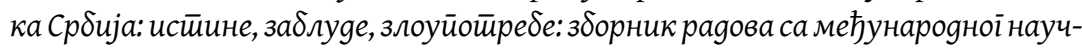

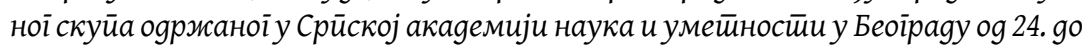

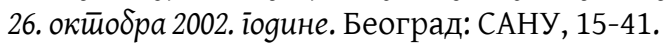

Екмечић, М. (2007). Дуго кретање између клања и орања: Историја Срба у Новом Веку 1492-1992. Београд: Завод за уџбенике.

Екмечић, М. (2007). Балканска политика Аустро-Угарске после Берлин-

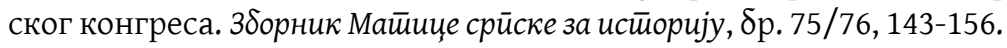

Љушић, Р. (1993). Књига о Начертанију. Национални и државни програм Кнежевине Србије (1844). Београд: Београдски издавачко-графички завод.

Мијатовић, Ч. (1892). Кнез Милош и пуковник Хоџес. Грађа за историју прве владавине кнеза Милоша. Сӣоменик, XVII, Београд: Српска краљевска академија. 
Милићевић, М. Ђ. (1893). Кнез Милош прича о себи. Београд: Српска краљевска академија.

Стрњаковић, Д. (1939). Како је постало Гарашаниново Начертаније. Сӣoменик САН, ХCI, 70, Београд: Српска краљевска академија, [65]-115.

ЈОВАН Ј. АЛЕКСИЋ

УНИВЕРЗИТЕТ У ПРИШТИНИ СА ПРИВРЕМЕНИМ СЕДИШТЕМ

У КОСОВСКОЈ МИТРОВИЦИ, ФИЛОЗОФСКИ ФАКУЛТЕТ

КАТЕДРА ЗА ИСТОРИЈУ

Истражујући за потребе докторске дисертације на тему „Живот и дело Милорада Екмечића (1928-2015)“, запазили смо да је овај еминентни југословенски и српски историчар у једном периоду своје каријере показивао нарочито интересовање за одгонетање одговора на питање ко је прави креатор „Начертанија“ незваничног спољнополитичког програма Кнежевине Србије. Полазећи од принципа да у историјској науци ништа није до краја откривено, ухватио се у коштац са готово аксиоматском тврдњом о Илији Гарашанину као аутору овог списа. Благодарећи вишедеценијском истраживачком искуству, вансеријској ерудицији и добром познавању архивске грађе и релевантне литературе успео да је стави под критичку лупу. Открио је податке који бацају сасвим ново светло на позадину настанка овог документа. Показао је да „Начертаније“ заправо није било плод српске политичке мисли, већ дело тројице европских дипломата и државника, који су из својих интереса сачинили план српског националног уједињења у склопу југословенске заједнице. Целу историју овог документа пратиле су бројне контроверзе, које је Екмечић, захваљујући исцрпним архивским истраживањима и ишчитавањем томова и томова књига успешно рашчивијавао. Исти је случај и са злонамерним оценама и оптужбама на рачун „Начертанија“, које су, према Екмечићевим оценама, готово по правилу биле ваннаучне и служиле као идеолошко оправдање за експанзију других сила на рачун српских интереса. Чини се да је најцелисходнији суд о најзначајнијем српском спољнополитичком плану 19. века изнео у Сӣварању Jуїославије кроз речи да На- 
чертаније није плод домишљања Илије Гарашанина, нити његовог саветника Франтишека Заха, па ни делатности кнеза Адама Чарториског, већ да је то „исцеђен сок српског историјског искуства борбе за самосталну и демократску државу од времена сукоба кнеза Милоша са руском дипломатијом 1833 (...) резултат проверених веза са представницима околних националних покрета“. Својим оштроумним и акрибичним опсервацијама о историјском смислу и циљевима, али и о различитим тумачењима суштине „Начертанија“, подарио је још један значајан допринос овдашњој историографији.

КљУчнЕ РЕчи: Милорад Екмечић, Начертаније, Илирски покрет, Дејвид Уркварт, Адам Чарториски, Франтишек Зах, Илија Гарашанин.

Овај чланак је објављен и дистрибуира се под лиценцом Creative Commons Ауторство-Некомерцијално Међународна 4.0 (СC BY-NC 4.0 |

https://creativecommons.org/licenses/by-nc/4.0/).

This paper is published and distributed under the terms and conditions of the Creative Commons Attribution-NonCommercial International 4.0 licence (CC BY-NC 4.0 | https://creativecommons.org/licenses/by-nc/4.0/). 